\title{
Sedimentary Ce anomalies: secular change and implications for paleoenvironmental evolution
}

\author{
KUN ZHANG AND GRAHAM A SHIELDS
}

University College London

Presenting Author: kun.zhang.19@ucl.ac.uk

Due to its redox sensitivity, the Ce anomaly preserved in sedimentary rocks has been widely applied to reconstruct seawater redox states [1]. However, there is so far no relatively complete $\mathrm{Ce}$ anomaly compilation, hindering our understanding of oceanic redox evolution. Here, we report a novel compilation of $>2000$ screened Ce anomaly data from chemical sedimentary rocks of Archean-Phanerozoic age, including carbonate rocks, iron formations, phosphorites, and cherts, deposited in different environments. The temporal variations in $\mathrm{Ce}$ anomalies are mostly consistent with the present consensus around oceanic redox evolution. Nevertheless, pulsed oxygenation events in the mid-Proterozoic are evidenced by profound negative $\mathrm{Ce}$ anomalies. Statistical analyses suggest an overall gradual oxygenation in the late Tonian to the early Cambrian. While shallow marine environments were broadly well oxygenated during the Proterozoic-Phanerozoic transition interval, the deep ocean remained largely anoxic, consistent with the persistence of a dissolved organic carbon reservoir that acted as a redox buffer. Statistical analyses indicate that pervasive and sustained ocean oxygenation was probably not achieved until middle Devonian times, potentially related to the evolution of secondary woody tissues and forests. According to a thermodynamics-based $\mathrm{Ce}$ oxidation model [2], atmospheric $p \mathrm{O}_{2}$ could have been as high as $3 \%$ PAL during the mid-Proterozoic and 9\% PAL in the late Ediacaran-early Cambrian, which is broadly consistent with previous estimates. We concur that the marine sedimentary $\mathrm{Ce}$ anomaly responds sensitively to oceanic redox changes and is a reliable proxy to track Earth system evolution.

References:

[1] Wallace, M. W., Shuster, A., Greig, A., Planavsky, N. J., \& Reed, C. P. (2017), Earth and Planetary Science Letters 466, $12-$ 19.

[2] Liu, X. M., Kah, L. C., Knoll, A. H., Cui, H., Wang, C., Bekker, A., \& Hazen, R. M. (2021), Nature Communications 12(1), 1-7. 